\title{
SHAPING SWIFT'S EXPRESSIVENESS THROUGH THE TRANSLATION OF HIS METAPHORS IN ALBANIAN LANGUAGE
}

\author{
Alma Karasaliu ${ }^{1}$
}

\begin{abstract}
Metaphors have become the focus of a wide variety of discussions in the field of translation theory and practice. They are important rhetorical devices with cognitive function that have been thoroughly studied and considered important by various scholars. Taking into consideration the difficulties implied with identifying and translating such devices, this article aims to identify the procedures employed in translating some of the metaphors present in "A Tale of a Tub" and "Gulliver's Travels", two of the most prominent satires of Jonathan Swift. In this context, based on the translation procedures suggested by Raymond van den Broeck, special attention is given to the formal characteristics and efficiency of the relevant devices in the target language and the degree to which the originality of the message intended by the author in the source language is conserved and conveyed in the target language, with focus on the culture compatibility between both target and source languages. Finally, the high level of naturalness and presence of various translation procedures employed in the conveyance of metaphors in both works is stated, emphasizing the use of an additional approach, not mentioned in either the procedures suggested by van den Broeck or those suggested by New mark.
\end{abstract}

UDC Classification: 81'25, DOI: http://dx.doi.org/10.12955/cbup.v4.775

Keywords: translation procedures, cultural differences, naturalness, adaptation.

\section{Introduction}

Metaphors, defined as words that shift from normal usage to another form, apart from aesthetical values, are acquired by the superposition of cultural features on referential ones and provide a useful cognitive meaning of our world. Consequently, their study is considered of high interest, based on their cognitive features and the frequency of which they are encountered in language. Among other sciences, translation serves as a bridge between two or more cultures of countries, and thus, understanding this rhetorical device becomes crucial. Due to the complexity of metaphorical meanings, the process through which metaphors are translated from one language to another is considered difficult. As such, research studies on this topic have been relatively incomplete, owing partly to this device being viewed as part of figurative speech. In this context, Mandelblit (1995), a supporter of the cognitive approach to translating metaphors, believed that such an important linguistic form, encountered not only in the works of literary character, but also in everyday speech, requires special attention. In this context, the cognitive approach towards metaphors, more so than figurative values, centers on how they are conceived, thus building a metaphorical map. Similarly, Lacoff and Johnson (1980) claimed that living through a metaphor means classifying the surrounding reality through it and conceiving one's perceptions and actions on that reality.

\section{Translating metaphors}

Kokona (2003) considered the process of translation as an opportunity for people to obtain awareness of each other, and that metaphors, frequently employed in every language, are one means through which this process is carried out. In this context, we note that their conveyance carries various difficulties among which the intercultural and inter-lingual discrepancies are notable, similar to the effort required in trying to understand their original message. These aspects considerably complicate the process of translation. According to Menachem Dagut (1976), establishing a definite rule for translating metaphors from one language to another is impossible. Given that various combinations of semantic fields of one or more lexical units are involved in forming these rhetorical devices, their interpretation becomes more difficult, especially where related features of the employed semantic fields are unknown for the translator. Encountering metaphors or metaphorical expressions, which pose difficulty in understanding, may also be due to newly created metaphors that absent from dictionaries because they have not been fully lexicalized. In this respect, Dagut (1976) lists two influential factors in the translation process: cultural elements (and their semantic relations), and intercultural relationships between the source and target languages. In discussing the translation of

\footnotetext{
${ }^{1}$ Alma Karasaliu, Department of Foreign Languages, Faculty of Education and Philology, Fan S. Noli University, Albania, almakarasaliu3@gmail.com
} 
metaphors, Newmark (1988) mentions the difficulty in understanding and translating an original, adapted or stock metaphor lies in identifying the relationship between the object and the image, and whether their agreement relies on primary or secondary meanings of the word.

While reiterating the difficulty that creates variety in cultural conceptualization during the process of translation, which, somewhat, blurs the translator's concentration from determining or establishing equivalent variants, we are inclined towards a process focused on cultural conceptions. This is the most appropriate way of conveying the full message of the writer and creating a similar perceptive for the reader, who can accept it as appropriate even with the translated metaphor failing to structurally match the respective meaning of the source language (SL). Further, Snell-Hornby (1995) believed that the translatability of a text varies according to the cultural specificities of the SL as well as the cultural similarities in time and space between the source and target language (TL). Thus, considering metaphors were a cultural phenomenon and combining cultural elements with semantic ones was important, a thorough evaluation of the degree in which the metaphor could be adapted to the culture of the TL was advocated before its conveyance. Van den Broeck (1981), likewise, considered the translation of a metaphor as an empirical phenomenon, based on defining useful rules and strategies for the translator, while underscoring the important influence of linguistic and extra-linguistic factors in determining the metaphor's translation procedure.

\section{Translation procedures according to Newmark}

As Newmark writes (1988), the difficulty in translating metaphors from one language to another, lies in their formation characteristics. In this context, cultural metaphors pose more difficulties during the process of translation, than universal ones, which are present in the lexicon of many peoples, and to the personal ones (original). He suggests six different procedures for the translation of this rhetorical device:

1. Literal translation, for use in translating 'dead' and especially 'original' metaphors;

2. Literal translation of the metaphor accompanied with its paraphrased version;

3. The metaphor is paraphrased in the TL, while translating clichés, which are mostly encountered in informative texts, to preserve the ideas intended for the reader of the TL;

4. The metaphor is conveyed in the TL using another expression with the same function for use mainly with standard metaphors;

5. The metaphor in the SL is translated with a similitude in the TL;

6. Delete the metaphor, depending on metaphor's role in the SL.

Notably, Newmark's work was more than a classification of translation procedures. It aimed to equip the translator with specific variants for each type of metaphor, depending on form and character of the text in which it was used. This instructive way, basically facilitates the work of the translator, as identifying and determining the type of metaphor are pivotal in basing the translated variant in the TL.

\section{Procedures in translating metaphors in "A Tale of a Tub" and "Gulliver's Travels"}

As Kokona (2003) wrote, a skilled translator should be able to study the 'conditions of the life', 'the nature of the language,' the 'characteristics' of the writer and, at the same time, be able to shift these to the country of the TL. In this context, considering the attitude of previously mentioned researchers on the topic, it can be said that translating a text from one language to another comprises a lengthy procedure that requires skill and dedication. In addition, the style of the writer is very important, especially with the wide variety of figurative language that further complicates identifying and conveying the implicit messages that underlie the statements.

The data for this article were collected through randomly selecting fragments from the literary works: "A Tale of a Tub" and "Gulliver's Travels", both by Jonathon Swift. This approach was effective given the high frequency of metaphors in these two works. Only in the third chapter of A Tale of a Tub and Other Works (1958), translated in 1980, are 65 metaphors and metaphorical expressions encountered that were conveyed into the TL through a wide range of translating procedures. Also, only in the first voyage of Gulliver's Travels (1961), translated in 1958, are more than a hundred metaphors highlighted. Accordingly, prominent examples have been selected from both works, each representing the application of procedures suggested by Newmark (1988). 


\section{Metaphors Conveyed into the TL Through Literal Translation}

In the below expression, we see a comparison between a free individual and a free heart.

"I am sure my Heart was wholly free." (Gulliver's Travels, p. 36).

"Po sa për këtë, unë e kam shpirtin fare llagar ..." (Udhëtimet e Guliverit, f. 64).

The basis of this metaphor is the term 'Heart', while the rest is added information. The relationship between the elements in the above expression is modulation (specification), as the term 'heart', which according to the context refers to the conscience of Gulliver, acquires subsidiary qualities. In this case we are dealing with an implicit metaphor, which is Swift's original construction as such a variant is still not present in the dictionary of English language (Macmillan Education, 2007).

As seen from the above example, Halit Selfo, the translator of the book, provided the Albanian reader with a metaphorical expression formed by focusing on the semantic elements. In this aspect, we first note the shifting of some layers where the concept 'heart' is substituted by another abstract one, 'shpirt' (spirit). Even though the concept of 'heart' is fundamental in the metaphorical expression in question, its replacement with spirit, which shares the same structural values, is appropriate due to more than 'heart' in itself being implied with the writer aiming at implicating 'the spirit' and the individual's outlook. Related to the same expression, is another substitution. While the word 'spirit' is a connotation of the word 'heart' in the bilingual dictionary of Qesku (2005), the word 'llagar' in the expression 'llagar fare' stands for the English 'wholly free', which absent from Today's Albanian Language Dictionary (1980). It is a dialectal term, which can be a very prominent choice in the case where the reader is familiar with its usage, but may lose its impact in the case of a reader who sees it for the first time.

Regarding the syntactical aspect, we note the efficiency with which the translator preserved the relationship between constituent elements within the metaphorical expression, and focused on conveying a naturalized variant into the TL.

A similar example of literal translation is the following, taken from A Tale of a Tub:

“... that their Writings are the Mirrors of Learning." (A Tale of a Tub, p. 317).

“... se shkrimet e tyre janë pasqyrë e diturisë.” (Përralla e Fuçisë, f. 297).

As can be seen, in the above expression, 'the mirror' is the metaphorical part of the expression, built on a single unit, making it an explicit metaphor and thus facilitating its identification and translation. The comparison in this expression of likening a mirror, as a reflecting object, to the writings, which identify elements of the intellectual level of the individual, gives a referential relationship to the concepts of the expression.

Regarding the option chosen by the translator, we consider, that while preserving the basic concept of the metaphor, the direct part of the exponent is conveyed by the term 'dituri' (wit), a variant present in Qesku's (2005) bilingual dictionary. This metaphor refers to critics of the SL, who carry considerable marks of irony about their perception as holders of unfathomable knowledge. Maintaining the original form of this expression and converging it with the Albanian one allows the translator to convey the writer's implicit irony to the Albanian reader.

Metaphor's Literal Translation is Accompanied by Its Paraphrased Version

During the comparative analysis, translators sometimes have seen it appropriate to combine different translation methods. This has been aimed at detailed transmission of Swift's semantic elements and rhetoric, in each of his works. Below is an example taken from A Tale of a Tub.

“... he most valued a certain set of Bulls..." (A Tale of a Tub, p. 68).

“... më shumë nga të gjitha vlenin një çift demash, ${ }^{2}$...” (Përralla e Fuçisë, f. 304).

The above expression 'set of Bulls', is a reference to the orders issued by the papacy during that period. In the MEDFAL dictionary the term 'bulls' is defined as: 'Statements from pope' (statement

\footnotetext{
${ }^{2}$ With 'papal bulls' the writer means the austerity taken by the Holy See against the infidels and its adversaries; such measures were cursing and excommunication.
} 
issued by the papacy). In this case, we are dealing with a lexicalized formation, which means that, for the English reader, it is a perfectly natural expression. Furthermore, despite being built on the concept, 'set' (group), the term 'bulls' carries a figurative meaning and, therefore, involves the reader's attention on its own referent. Building the comparison between a representation of a powerful animal and very important documents, the author gives the constituent elements a quantitative modification of the relationship that leads the semantic function of the phrase into emphasizing and implicating irony towards the proclamations in question.

The conveyance of this metaphor carries considerable difficulty, not only at the conceptual level, but also at the semantic one. Given an expression of this kind is absent from the Albanian lexicon, the exploitation of literal translation as the most appropriate variant would result in a highly complex and incomprehensible expression for the reader, who may not be accustomed to conceiving a reference to papal ordinances through the combination of that concept with the new chosen one. In this case, we note that aiming at a full conveyance of the intended information, the translator has employed literal translation and accompanied this with more detailed explanations in the footnotes. Moreover, it is worth mentioning that despite not dealing with the original work of the author, the choice of this translation procedure can be regarded as particularly striking because the way and the context in which this expression is delivered gives it significant value, and this is important in the perception of the Albanian reader.

“... that I would never be an instrument of bringing ..." (Gulliver's Travels, p. 35).

“... se unë nuk do të bëhesha kurrën e kurrës një vegël e verbër në duart e tij, për të ..." (Udhëtimet e Guliverit, f. 63).

In terms of semantics, the function of the metaphor in the above example is specifying. The figuratively used part is the phrase 'to be an instrument', and the theme is the pronoun ' $I$ '. The metaphor coordinates the functions and the qualities of an object (an instrument) with those of an individual, Gulliver, who becomes an instrument in the hands of others.

The translator employs literal translation to convey the lexicalized metaphor, preserving the semantic relationships between the doer and the receiver of the action. As such, the metaphorical expression in the TL is built on the same basic concept as the one in the SL, and is further accompanied by another lexicalized one, 'vegël e verbër' (blind tool), offering the Albanian reader two interesting explicit metaphors, mingled as one in a single phrase.

The Metaphor is Paraphrased in The Target Language (TL)

As Newmark (1988) emphasized, the procedure of paraphrasing metaphors is frequently employed by the translators, especially in the languages of different cultural mappings. Nevertheless, it is important to mention that in the books in question, this procedure does not exceed the use of others. The examples below are representatives of such usage.

“... for the Public Good and Ease of all such as ..., Friends fallen out, ...” (A Tale of a Tub, p. 319).

“... për të mirën e përgithëshme të shoqërisë dhe për lehtësinë e madhe të të giithë atyre që ..., miqtë e rremë dhe ata të rënë nga vakti, ..." (Përralla e Fuçisë, f. 302).

In the above example, the word 'friends' forms the literal part of the phrase, while the phrasal verb of adjectival function forms the figurative part of the metaphorical expression. Given that no usage of this adjective as an adverb is found in the dictionary of English language (Macmillan Education, 2007), the extra acquired figurative meaning is quite evident. This leads the entire phrase into illustrating categories of people practicing confession as the subject of Swift's parody.

The corresponding element for the verb 'fallen out' in Albanian language is the intransitive verb 'bie, del', with no figurative use, and obliges the translator to adapt it with another phrase, in accordance with the conceptual and linguistic rules. At the conceptual level, the concept of 'friends' is brought to the TL with its respective element, while the metaphorical expression is substituted with 'e rremë dhe ata të rënë nga vakti' (fake friends who have lost their earlier influence and wealth). Considering the context, where the example in the SL is used, its paraphrasing, accompanied with an additional 
metaphor, provides the reader of the TL with an appropriate variant with connotations similar to the original one.

Below is an example taken from Gulliver's Travels:

"I begged his Patience to hear me tell my story..." (Gulliver's Travels, p. 150).

"Iu luta të më dëgjonte me durim, ..." (Udhëtimet e Guliverit, f. 173).

From a communicative approach, the verb 'begged' is the theme of the expression, while the phrase 'his patience' is used figuratively to give the elements of the metaphorical expression a predicative relationship. It is the author's original formation, built on the existing structures of the kind, 'to beg something'. In the example in question, the additional information stands between the verb 'to beg' and the phrase 'his patience', and judging from the context within which it is used, we can conclude that the writer aims to express gratitude towards the king, by making use of the connotations derived by the verb 'to beg'.

Regarding the way this metaphoric expression is translated, it is worth stressing that no important changes are observed at the syntactical or conceptual level. Likewise, the fundamental concepts presented in its structure, are skillfully preserved and conveyed in the TL with other respective ones. Moreover, the choice of the verb 'iu luta' for the English 'begged', though not found in the bilingual dictionary, is frequently used in Albanian language, while the avoidance of the pronoun 'I' does not lead to any loss in the shades of the meaning.

Translating a Metaphor in the SL with a Similitude in the TL

Apart from the abovementioned cases, the translated variants of the works in question contain cases in which explicit metaphors are translated into the TL by means of similitudes preceded by the particle 'posi' (like).

“... they had seen a swimming house" (Gulliver's Travels, p. 120).

“... se kishin parë një shtëpi, që pluskonte posi anije.” (Udhëtimet e Guliverit, f. 172).

Focusing our discussion on the structure and function of the metaphor in question, in terms of communication, we note that the theme of the metaphorical expression 'a swimming House' is the noun, 'house'. The similitude is formed by relating a boat to a house, leading the constituent elements of the expression to modulating relationships.

The translation of this original metaphor is carried out by means of a similitude preceded by the particle 'posi' (like), functioning as an explanatory part. Conceptually speaking, by employing the original concept (house), the translator extends the phrase to use the denotative meaning of the adjective 'swimming', which carries the new information in the metaphorical expression.

Another example of this kind is the one below:

“... which ... took to be a Feat of Art, ...” (A Tale of a Tub, p. 321).

“... të cilën ...e konsideronin si një marifet artificial e të stisur ...” (Përralla e Fuçisë, f. 305).

In the above example, the figurative part of the metaphorical expression is the term 'feat', while the denotatively used part is the term 'art'. Thus, the similitude is achieved by approaching physical a feat as one in the field of fine art. This partly-lexicalized metaphor, with no present combination of the term feat with 'art' in the dictionary, is conveyed in the Albanian language as a similitude, preceded by the particle 'si' (like). As noted in the example, the shifting of various levels is observed in the translated version. Thus, the basic concept, 'feat', is substituted with the phrase 'një marifet artificial e të stisur' (an artificial and staged gimmick), under semantic changes, where the incorporated shades in the meaning of the concept 'bëmë' (did) are simplified and transferred to a more positive perspective, at the same time, losing the greatness it implies. In terms of the pragmatics, the intentional avoidance of the term 'art', though not essential, diverts the reader's attention, thus deflecting the conveyance of the writer's original metaphor. This decision might be the result of an effort to transmit a more simplified version, which, in our opinion is unnecessary because in terms of concepts and linguistics, the option 'një bëmë/arritje arti' (an artistic feat) would be more appropriate, especially when 
accompanied by an additional expression. Nonetheless, apart from denying the reader the opportunity of encountering the original expression of the writer, the use of this synonymic pair simplifies the process of understanding by the reader.

\section{Deletion of the Metaphor}

Avoiding the metaphoric expression in the TL is a phenomenon mentioned, not only by Newmark (1988), but also by van den Broeck (1981).

“...; all intercourse between the two Empires having been strictly forbidden during the War, Upon Pain of Death; ..." (Gulliver's Travels, p. 32)

“... meqë në mes të dy vendeve udhëtimet qenë ndaluar prej një kohe të gjatë.” (Udhëtimet e Guliverit, f. 60).

Despite removing important semantic elements, the translator of Gulliver's Travels has deleted metaphors in various cases. The theme of the above explicit metaphorical expression, 'upon pain of death', relates to the term 'forbidden', building the comparison between punishment, due to disrespect, and the pain of death. Regarding the way this expression is translated into Albanian, we notice the total avoidance of the expression 'upon pain death', which, in the above context serves to reinforce the gravity of an existing rule. Even though the reader in the TL has been conveyed the intended message, there is a shift on the conceptual level, as the predicate 'qenë ndaluar' (were forbidden) replaces the original one and is accompanied by an adverbial phrase of time. The latest change might have been caused by the need to adapt the metaphorical expression with corresponding Albanian structures, though, in our opinion, the loss of such expressiveness is significant.

\section{The Metaphor is Conveyed in the TL Using Another Expression with the Same Function}

The transmission of metaphors of conceptual character through corresponding ones, characteristic of the language in which the translation is realized, is commonly encountered in the translated variants.

"... the Originals of Nature being depraved in these latter sinful ages of the World ..." (A Tale of a Tub, p. 320).

“... ku modeleve origjinale u mohoet e drejta e ekzistencës në këto kohët e mëvonëshme të kësaj bote mëkatare; ...” (Përralla e Fuçisë, f. 304).

In the above example, the phrase, 'ages of the world', stands as the theme of the metaphor, while the term 'sinful' carries additional information. We see that the constituent elements of the explicit metaphorical expression have a modifying relationship. Because no such usage is found in the dictionary, the translator, Shpëtim Mema, saw it appropriate to convey this original metaphor as another one, bearing the same semantic characteristics. In such a case, the perseverance of the concept 'sinful' in the translated version is worth mentioning. This indicates the translator's attempt to convey an expression, easily understood by the reader, as close as possible to the original form.

"And, as Truth always forceth its Way into rational Minds; ..." (Gulliver's Travels, p. 121).

"E, meqë e vërteta bën kurdoherë fole në ata që hanë arsye, ..." (Udhëtimet e Guliverit, f. 173).

In the above example, the predicative relationship between the theme, 'truth', and the added figurative one, 'forceth its way', raises a comparison between the truth and the skillful individual, thus giving human qualities to an abstract noun. This metaphorical expression is brought to the reader of the TL by means of two other metaphorical expressions: 'bën kurdoherë fole' (makes whenever a nest) and 'në ata që hanë arsye' (in those with reason). The first metaphorical expression, having as its theme the concept 'e vërteta' (the truth), is substituted with another, with the same functional characteristics, but with different lexical form, the figurative nuances of which are expressed through other elements, typical for the Albanian language. The second expression, on the other hand, is extended in the translated version, providing the reader of the TL with an explicit metaphor, in contrast to that which is implicit in the SL. 


\section{Simple Phrases Translated with Metaphors ${ }^{3}$}

A prominent feature, worth mentioning in this part of our paper, is the use of a set of conceptual metaphors in translating simple phrases, with the view of adequately communicating and adapting text from the SL to the TL. Ultimately, this phenomenon, provides the translated text with a variety of figurative connotations, adding some of the translator's personal creativeness, which arise on the basis of the information derived from the denotative meaning of the original text.

“... leaving me almost in the Dark." (Gulliver's Travels, p. 117).

“... se dhoma zhytet në terr." (Udhëtimet e Guliverit, f. 169).

Regarding the example above, it is noted that the literary phrase 'leaving me almost in the dark', is skillfully conveyed in the TL by means of the metaphorical expression, as underlined above. The concept 'dhoma' (room), corresponding to 'the box' in the original context, is the theme, while the verb 'zhytet' (dives) gains figurative qualities, bearing the predicative relationship of action. In terms of semantics, the translated version possesses higher expressiveness, which is neatly mingled with the original nuances of the meaning.

A similar example is observed in another satire:

“... I was plentifully instructed, by a long Course of ..." (A Tale of a Tub, p. 314).

“... unë jam armatosur deri në dhëmbë prej një periudhe të gjatë ...” (Përralla e Fuçisë, f. 293).

In the above example, no figurative usage of the underlined phrase is noticed, while in the translated version the use of a metaphorical expression with the theme has the concept 'I armatosur' (armed). It is worth mentioning that the employment of this metaphorical expression by the translator seems highly efficient in its context. In this respect, it is worth emphasizing that despite the extra information added, the translated variant carries some personal writing qualities of the translator, and as Nida (1964) suggests about the translation process, semantic equivalence is more important than a formal one.

\section{Conclusion}

In summary, it is worth emphasizing that the exploitation of a variety of translation procedures was observed in the process of translating metaphors and metaphorical expressions in each of the translated books considered. The reasons that have led translators to these decisions may be different, but we reason that a great deal relies on cultural differences, and much involves the way in which the world is conceptualized in each of the languages. These divergences, along with linguistic peculiarities of both languages, seem to have been involved in choosing the translation procedures used. In this context, the translator's main goal to translate these rhetorical devices through naturalized linguistic combinations is accompanied by an effort to convey the messages and implications of the original metaphorical expressions in the closest way possible to the target language.

\section{References}

Dagut, M. (1976). Can Metaphor be Translated? Babel XXII (1), 32.

Kokona, V. (2003). Mbi Përkthimin, me përkthyesin, Shtypshkronja Edlor, 18.

Lakoff, G., \& Johnson, M. (1980). Metaphors We Live by, Chicago: University of Chicago Press, 12.

Macmillan Education (2007). MACMILLAN English DICTIONARY FOR ADVANCED LEARNERS, Second Edition, New Edition, p. 531.

Mandelblit, N. (1995). The Cognitive View of Metaphor and its Implications for Translation Theory, Translation and Meaning, Part 3, Maastrict: Universitaire Press, 485.

Newmark, P. (1988). A textbook of Translation, London: Prentice Hall International (UK) Ltd, 105.

Nida, E. (1964). “Toward a Science of Translating”, Leiden: Brill, 492.

Qesku, P. (2005). Fjalor Anglisht-Shqip, Botime EDFA, 230

Snell-Hornby, M. (1995). Translation Studies: An Integrated Approach, Revised edition, Amsterdam/ Philadelphia, John Benjamins Publishing Company, 41.

van den Broeck, R. (1981). The Limits of Translatability Exemplified by Metaphor Translation, Poetics Today, Vol. 2, No. 4, Translation Theory and Intercultural Relations (Summer - Autumn, 1981), Duke University Press, 74.

\footnotetext{
${ }^{3}$ No such procedure is mentioned by Peter Newmark or by Raymond van den Broeck.
} 